\title{
Mapping factors that support social integration of minangkabau community in Luhak Agam
}

\author{
Siti Fathimah ${ }^{1}$, Fitri Eriyanti ${ }^{2}$, Erianjoni ${ }^{3}$ \\ 123 Universitas Negeri Padang, Padang - Indonesia, (sitifathimah98@yahoo.com)
}

\begin{abstract}
Domain origin of Minangkabau is divided into three Luhak known as Luhak Nan Tigo. This region is the center of Minangkabau cultures. The three Luhak are located in West Sumatera. Those areas also have a diversity of ethnicity, religious, and customs. This study aims to formulate the factors which support social integration of Minangkabau community. By using descriptive qualitative approach, the informants of this research are the elements of regional leaders, youth leaders, custom leaders, religious leaders and ordinary citizens. Techniques of data collection was observation, interviews, and documentation. The result of the research found that the strong traditions that still make Minangkabaupeople to feel a unity, their customary laws in Minangkabau region makes the people feel protected and not be afraid to break the rules of the customs. Customary laws become a life principle of social life at the same guidelines with the aim of creating security, discipline and creating a virtuous society and noble characters.
\end{abstract}

Keywords: social integration, minangkabau

\section{Introduction}

In a society there are differences from one another, such as differences in social status, ethnicity, race, religion, language, and culture. In order to coexist all of the differences, it is necessary to harmonize these differences in order to achieve the unity of life in both social or state associations.

According to Soerjono Soekanto (1986: 61), social integration will occur between the individual and the individual, individuals and groups, and groups and groups. The integration will arise because of the orientation of the inter-social elements have the feeling of in-group to their group, and there is another group outside of the group (out-group). Usually the cooperation will be stronger if there is a danger from outside or there are acts from the outside to offend the people in the group. Cooperation will be aggressive if in the long term experienced of disappointment as a result of feeling dissatisfied and unfulfilled desires because there are obstacles that come from outside of the group.

In this case Elly M. Usman Setiadi and Kolip (2010: 390), explained that the integration between the members of genetic relationship would happen if each member of the relatives obey the norms and values that prevailed in the kinship system. If there are several members of kinship do not comply with the values and norms, the kinship system is declared no longer integrated. Likewise with the community integration, JP and JL Gillin Gillin in Elly M. Usman Setiadi and Kolip (2010: 390) defined community as "the largest grouping in which common customs, traditions, attitudes, and 
feeling of unity are operative". Derived from that definition can be concluded as (1) a group of people that live in a particular region, (2) reside in a long time, (3) there are rules of life such as common customs, traditions, attitudes, and feeling of unity, (4) sense of identity among the citizens.

This integration will be achieved if the people's life has fulfilled all of the elements, otherwise if one of the elements in these communities are not fulfilled, then the society is not integrated. As well as Gillin and Gillin above, Turner (1978: 6) explained that the society was to be viewed as an entity in itself that should be distinguished from, and was not reducible to, its constituent parts. In conceiving of society as a reality, being suigeneris. Society should be regarded as an entity (entity). As an entity, the society can be distinguished by its parts, but cannot be separated. Regarding the society as the reality of suigeneri (a reality that cannot be doubted its existence).

Likewise the Minangkabau society in Luhak Agam region. Based on tambo, the domain origin of Minangkabau region is divided into three Luhak known as LuhakNan Tigo, one of them is Luhak Agam. As the capital area of Minangkabau region, this are became a cultural center of Minangkabau society. Luhak Agam is located in one of Indonesian province, West Sumatera. This area also has a diversity of ethnicity, religion, and customs. For example, like in Bukittinggi as a part of Luhak Agam. As one of the region Minangkabau origin, Bukittinggi has the potential high heterogeneity of society in terms of ethnicity, religion, and customs. It is also found in other districts / cities in the territory of other Minangkabau. All of the diversities has possibility to cause a conflict and disunity, but also can unite all of community in other region in Minangkabau.

Muttukrishna Sarvananthan (2012: 109) also noticed that the presence and development of local government fiscal devolution will decrease economic inequality and ethnic conflict between the center and regions in Sri Lanka. It is also obtained based on the information from one of the newspapers of West Sumatra (Singgalang: 2016), explained that the first process to solve the problems to follow up the case in some areas in West Sumatra is by doing mediation through consultation between ninik mamak from both parties and figures in the community that resulted an agreement signed together. This condition can also be seen at the time when the problems of assignment of mamak in the community in the mamak Gadut, Bukittinggi. Same as the findings of Eriyanti Fitri (2007: 32) regarding malakok, is a traditional institution in the social structure of Minangkabau. In the ranking of structure, malakok is one way to strengthen the social structure of society. By malakok, the immigrants can be accepted in the social structure of Minangkabau. If everyone is in the social structure would have been a form of understanding, there is no prejudice attitude, they help each other, so that the peace in community nurtured. Furthermore Fitri Eriyanti (2013: 80) explained that social integration is created by their traditional leadership role in the structure of Minangkabau society and social integration occurs in the attitude and mentality of Minangkabau society that is opened and tolerant.

Not only that, Lindayanti and Witrianto (2014: 6) also noticed that the custom role also has its own pretext to harmonize the life of various ethnic groups living in East Tanjung Jabung Regency, MalayJambi custom. Retnowati (2014: 195) also found the same thing in society of Situbondo, the integration and reconciliation efforts have been made by community and religious communities in Situbodo. One effort to deal with conflicts is to do meetings and workshop-gatherings on a regular basic by the Reverend Father and Kiai, in order to discuss the issues about religious life. Furthermore, it also carried out to make the peace agreement and humanitarian cooperation together.

Based on the conditions above, the researchers are interested in finding the positive side of being supporters of the integration of Minangkabau society, although there are possibilities of conflicts in the society cannot be eliminated. From the condition of Minangkabau people who are in Agam Luhak this, researchers are trying to map out the factors that support and hinder the integration of Minangkabau society. 


\section{Method}

This research is a descriptive study using a qualitative approach. Setting of the study was conducted in the area of AlamMinangkabau, DarekMinangkabau region; LuhakAgam in NagariKamangMudiak, Agam Regency and GantiangManggis Village, Bukittinggi. Those regions are one of the domain origin of AlamMinangkabau with the regional characteristics and high heterogeneity in both ethnicity or religion and strong customs in Minangkabau. The informants of the research are the elements of regional leaders (walinagari), the element of youth, custom leader's element, the element of religious leaders and ordinary citizens (immigrants and natives). Data collection techniques used is by making observations to Bukittinggi and Agam, include the activities of the local culture and governance who has roles to create the social integration in Minangkabau society in LuhakAgam. The second technique is through interviewing the informants, also documentation of cultural activities of Minangkabau community and government, organizational structure, historical records regarding Minangkabau society and so on. To establish trustworthiness, the data required inspection of techniques used in this study is triangulation. Data analysis techniques used using data analysis techniques with models Miles and Huberman (2009) because this model is one model of data analysis for the study using a qualitative approach.

\section{Results and Discussion}

1. The Local Elements of Socio-Cultural Factors which Become Supporting Potential of Social Integration of Minangkabau society in LuhakAgam.

In Minangkabau society, religion is very important in life. It is seen in the philosophy explained that adat basandi syarak, syarak basandi kitabbullah. Islam is the identity of Minangkabau society. Thus, every Minangkabaunese is an obligatory to be a Muslim, and if not Muslim, they are considered not as a part of Minangkabau community.

Besides, in every society, human beings cannot ignore the knowledge of fellow human beings. Many tribes have not been affected by modern psychology; in terms of associating with one another must be holding on to, for example, the knowledge of the types of faces (physiognomy), or knowledge of the body markings. In this group can also be included knowledge about social manners, customs, systems of norms, customary laws and so forth, and also knowledge of genealogy and the history.

In general, in the traditional Indonesian legal system there is an unwritten law and the law is not modified in a book of laws. It's an unwritten law called customary law, which is a synonym of the tradition law (Soekanto Soerjono, 1982: 10). Likewise with the Minangkabau in Luhak Agam, in this society there are known a customary law embodied in legislation on neighborhood and community life to create harmonious and conducive life. This law made as life guiding principle in society life with the aim of creating security, discipline and virtuous community and noble character, "Talatak sesuatu ditampeknyo, lamak di awak katuju di urang", "Padi masak jaguang maupiah, taranakbakambang biak, Bapak kayo Mandeh Batuah, mamak dihormati urang". With the existence of this rule makes the local community to follow the rules that prevailed in the community so that harmony can be created despite the inescapable conflict. However, although there is a conflict, it can be done problem-solving in accordance with the provisions of the applicable customs in Minangkabau society.

Based on the explanations above, socio-cultural elements in Minangkabau society can unite the society so that the social integration can be shown which is stated in the philosophical systems of indigenous based on the teachings of the Islam, language, art, kinship systems, and customs, which are still strong in the community life. This condition will be easily created if each individual 
(whether migrants or natives) each have of understanding about the meaning of togetherness in society which can be shown in the form of tribal institutions and the same belief, called Islam.

However, if these immigrants came from other than Islam, then each religion course must respect existing traditional disciplines. As long as the community of other faiths can respect the existence of the cultural identity of Minangkabau so that a good social relations in society can be created and vice versa. This of course is framed by a strong sense of tolerance of each parties. Besides, strong customs make the Minangkabau people feel the unity, by the customary laws prevailed in Minangkabau region makes people feel protected and not be afraid to violate the customs rules, so that conflicts or disputes can be decreased.

This condition as expressed by Emile Durkheim on social solidarity, both in rural and urban areas there is something that unites them. However, it is different between in rural and urban areas. Durkheim describes the two types of social solidarity in society, the society which is based on mechanical solidarity and organic solidarity. The subject matter of the idea is the question of what binds and unites people (Damsar.2015: 81). Thus things that can unite Minangkabau society is the social element of cultural life in the community itself, this condition is supported by the customary rules framed by the guidelines on the religion of Islam; adat basandi syarak, syarak basandi kitabbulah.

Based on this, it can be said that every society there is a collective consciousness, as stated by Durkheim in the form of the totality of beliefs and sentiments shared that on average there are at the same community members. Durkheim (1964) also explains that to create social integration, there must be values that are shared by individuals, such as the moral and religious values. This is what binds individuals in society. Damage to these values means the destruction of social integration. Later he explained that the community was originally drafted by individuals who want to meet the biological needs simultaneously. Those needs are eventually evolved into social needs. This collective permanence shaping societal values and makes people stay balanced. The collective consciousness, said Johson in Damsar a social solidarity that relates to individuals who have the same properties, conscience and religion and the same normative pattern anyway. Solidarity in all aspects of life to work as a social glue, in this context may be, values, customs, and beliefs that are shared by members of the public in the bond and collective consciousness or collective consciousness (Ambo Upe. 2010: 95).

Likewise with Paul E. Mott (1965) and Zanden (1979) suggests that there are several factors or strength that increase social integration, which is a sociocultural factors. In connection to that, Myron Weiner gives five definitions for integration. First, integration is defined as "the process of unification of different groups are culturally and socially into one unit area and form a collective identity. The last definition mentioned of integration as "... the behavior of integrative or the ability of people in a community to unite to achieve the same goal". That is, if the individual or group has norms, values, and beliefs are the same then they will be welded (bonded) together through a network of shared culture. Even their integrity comes from this similarity. Their life activities are guided by mutual expect, so that culturally they are like "imitation carbon-copy" of each other (Weiner (1968: 264-265).

2. The elements from Local Government Policies that Supporting Potential Social Integration of Minangkabau society in Luhak Agam.

Doyle Paul Johnson (1986: 181) explains that social solidarity demonstrated on the state of the relationship between individuals and / or groups that are based on moral feelings and beliefs held together reinforced by shared emotional experience. However, Doyle Paul Johnson (1986: 204) also explains that social solidarity and integration may be seen as an example of a social fact which is beyond the individual and cannot be explained by individual characteristics. To understand the 
level and type of social solidarity contained in the society, it is necessary to analyze the social structure.

Based on the assumptions above, in the structure of Minangkabau society is composed of various social structures, starting from the village (the formal institutions of government) who have a partner of several cultural understandings, there is in terms of customs, institutions, PKK up to Bundo Kanduang which facilitates Minangkabau women either custom values, religion, and identity of Minangkabau women. The difference between social structure in Nagari Kamang Mudiak and Gantiang Manggis Village is the presence of Parik Paga and FKPM (Police Communication of Society Forum) in the social structure in the Kanagarian Mudiak Kamang. With the various social institutions is certainly an opportunity for the creation of high solidarity, help each other and work together in solving a problem. With the existence of these institutions and the whole society was collected united through which runs from the activities of each of stewardship. With the moral to follow the common rules applicable in the society then solidarity will form a harmonious in whole social disciplines.

3. Local forms elements of Minangkabau mentality as the Supporting Potential of Social Integration of Minangkabau Society in Luhak Agam.

Raso jo pareso, Means introspection or self-assessment, get used to strengthen the sense of humanity or conscience that is sublime in daily life. In facing problems we are required to familiarize themselves to be careful on researching to get the truth of the essentials and unhurried in action. Thus, the meaning of Rasoin customs is good behave as the saying goes as follows; nan kuriek iolah kundi, nan merah iolah sago, nan baiak iolah budi, nan indah iolah baso. The difference between Raso with Pareso referred to in the following maxim; Rasotumbuah didado (feeling grow from heart), pareso timbua di Kapalo (thinking arises in the head / brain). Thus, it can be said that custom values above teaches us how to think so that when Minangkabau people wanted to do something should consider many things carefully and thoroughly. The implication in the social integration is to consider the feelings, so when they wanted to do something, that person will think beforehand, so whatever the actions will not destroy others or themselves. The conflict can be avoided.

Togetherness values, in the social environment of Minangkabau society based on the applicable rules based on a sense of togetherness and solidarity. This will encourage solidarity and care for the feelings of others in daily life. These values are believed by the Minangkabau people which will ensure harmony in daily life. As stated in Minangkabau adage; adat nan maniru manuladan, sahino samalu, sarasosapariso. The mentality of the Minangkabau in Agam Luhak further support for the creation of social integration is fidelity or loyalty. According to Amir MS (2004: 103) a faithful (loyal) is courageous, feel kinship and united in kinship environment. This trait is the beginning of being helpful, defend each other and sacrifice for each other. If conflict occurs and Minangkabau people are forced to choose, they would stay by their relatives sides.

Meanwhile, custom is like a coin which has the two sides, on one hand it is related to "the law", with values which are specified by Bushar (1995), the law of familial customs, law of marriage customs, laws of inheritance customs, criminal law traditional, custom constitutional law, procedural law and the custom law of indigenous lands, in addition to ceremonial values are very distinctive and related to the other side. On the other hand, with regard to the demands of indigenous life, the basic principles of the teachings of our ancestors so that descendants can live well and sustainably. Because that's not wrong if the indigenous associated also with philosophy or worldview ethnic influence and mindset of an ethnic character.

Based on the findings in the field that mapping Factors that Support Social Integration of Minangkabau Society in Luhak Agam is the social elements of culture in Minangkabau society which can unite the community to create social integration stated in the philosophical systems of 
indigenous based on the teachings of Islam, language, art, kinship systems, and customs, which are still strong in the life of society. This is also supported by the government who facilitates the decentralization policy of the smallest villages as a social structure in the Minangkabau government system, for example, supported by the agency KAN, PKK, Bundo Kanduang, Parik Paga, FKPM and also by the mentality of the Minangkabau people who have loyalty, prioritizing Rasojo pareso, tolerance, and solidarity to other communities that create a peace among the society.

\section{Conclusions}

The conclusion of the authors about the Mapping Factors that Support Social Integration of Minangkabau Society: Studies in Luhak Agam, is Communities in Luhak have customs philosophical system based on the teachings of Islam, language, art, kinship systems, and customs, which are still strong in life. The community will be easily integrated when each individual (whether migrants or natives) have an understanding of the meaning of togetherness in society are realized in the form of tribal institutions and the same belief, called Islam. However, if these immigrants came from other than Islam, then each religion course must respect existing traditional disciplines. Throughout the community of other faiths can respect the existence of the cultural identity of Minangkabau to create harmony of social relations in society and vice versa. These are formed by a strong sense of tolerance of each parties. Besides, a strong and powerful customs make Minangkabau people feel of unity, with their customs law which applicable in Luhak Agam that makes the people feel protected and not be afraid to violate the customs rules, so that conflicts or disputes can be decreased. These custom laws made life guiding principle in society life with the aim of creating security, community discipline and creating virtuous and noble society.

People in Luhak Agam consists of various social structures, starting from nagari (the formal institutions of government) who has relation of several cultural angles, in terms of customs, PKK up to Bundo Kanduang which facilitate Minangkabau women either socialization values customs, religion until the identity of Minangkabau women. In Nagari Kamang Mudiak there are several different structures with the structures in the village of Manggis Gantiang, namely Nagari Kamang Mudiak which has social structure Parik Paga and FKPM (Police Communication of Community Forum). Various social institutions open the opportunity to create solidarity, help each other and work together in solving problems. People feel pooled and united through the activities of each stewardship. With the moral to follow the common rules applicable in the society so that solidarity can be shown and form a harmonious unity in whole social disciplines.

The attitude of the personality and mentality which is tolerant prioritized Rasojo pareso of society in Luhak Agam make this society can easily be integrated in a harmoniously and conducively. As long as their community members have these qualities so that the harmony can rapidly occurs. This mentality can even exceed the relationships of the tribe. This means that if there people who are good in building relationships among citizens, are preferred to be selected by the community as a leader in the village, and more prioritized to siblings and neighbors.

\section{Acknowledgments}

The author realized without any help of various parties, this article will not be accomplihed. In connection to this, the author would like to thank to all those who have helped in the completion of the Thesis. The author would like to thank honorably Ms. FitriEriyanti, M.Pd., Ph.D as the Supervisor I and Dr. Erianjoni, M.Sc., as Supervisor II who have provided inputs and advices in guiding the authors for completing this article. Beloved parents who have supported in prayer, moral and material to the author, all lecturers Padang State University Graduate Program who have trained and taught how to write, to all informants, and especially to all Graduate students colleagues of Padang 
State University, Studies Program of Social Sciences, who have given the time to provide guidance, advice and suggestions for the completion of this article.

\section{References}

Ahmadi, R. (2014). Metode penelitian kualitatif. Yogyakarta: Ar-Ruzz Media.

Bungin, B. (2003). Analisis data penelitian kualitatif. Surabaya: Raja GrafindoPersada.

Eriyanti, F. (2007). Malakok: Suatu mekanisme pendamai ala Minangkabau". Demokrasi, VI (2) 73-82.

Eriyanti, F. (2013). Aspe ksosio-budaya, kebijaka npemerintah, dan mentalitas yang berpengaruh terhadap integrasi sosial dalam masyarakat Sumatera Barat. Humanus, XII (1) 1-15.

Erwin.(2005). Solidaritas sosial dalam keluarga matrilineal Minangkabau. Dalam Alfan Mikodan Jendrius (Eds.), Ilmu sosial pembangunan dan perubahan sosial budaya (hlm. 22-240). Padang: ISBN.

Hann, D, David, N, and Edmund, H. (2016). Workplace conflict resolution in wales: The unexpected prevalence of alternative dispute resolution. SAGE, 1-27.

Harmantyo, D.(2007). Pemekaran daerah dan konflik keruangan kebijakan otonomi daerah dan implementasinya di Indonesia. Makara Sains, 11 (1) 16-22.

Habshy, H. (2017). 31 Maret. Begini penampakan massa aksi 313 di Istiqlal. Detiknews.

Hasanah, T. (2015). Potential social capital of Indonesian immigrant in Malaysia: A preliminary research. ELSEVIER, 211 (383 - 389).

Idrus, H. (1994). Pokok-pokok pengetahuan adat alam Minangkabau. Bandung: PT. Remaja Rosdakarya.

Johnson, D. P. Tanpatahun. Teori sosiologi klasisk dan modern jilid 1 dan 2.Terjemahan oleh Robert M. Z. Lawang. 1986. Jakarta: Gramedia.

Kahin, A. (2008). Dari pemberontak integrasi: Sumatera Barat dan politik Indonesia 1926-1998. Jakarta: Yayasan Obor Indonesia.

Miles, M, dan Huberman, M. (2009). Analisis data kualitatif (Terjemahan). Jakarta : UI Press. 